\title{
Bartholinitis due to Aggregatibacter aphrophilus: a case report
}

Morgane Choquet ${ }^{1}$, Emilie Pluquet ${ }^{1}$, Sandrine Castelain ${ }^{1,2^{*}}$, Raphaël Guihéneuf1,2 and Véronique Decroix ${ }^{1,2}$

\begin{abstract}
Background: Aggregatibacter aphrophilus, a commensal of the oro-pharyngeal flora and member of the HACEK group of organisms, is an uncommonly encountered clinical pathogen. It has already been described as the causative agent of brain abscesses, empyema, meningitis, sinusitis, otitis media, bacteriemia, pneumonia, osteomyelitis, peritonitis, endocarditis and wound infections. Herein we report the first case of bartholinitis due to A. aphrophilus.

Case presentation: A 33-year-old woman was admitted for a 3-day genital pain without fever and urinary functional signs. The abscess was incised and drained; $A$. aphrophilus was the only micro-organism that grew from the pus. The patient received no antibiotics; the clinical course was favourable.

Conclusion: This case highlights the importance of an effective treatment of recurrent bartholinitis such as a cold resection of the gland. It is presented for its rarity.
\end{abstract}

Keywords: Aggregatibacter aphrophilus, Bartholinitis, Gram negative coccobacilli, Capnophilic bacteria, Genital infections

\section{Background}

Aggregatibacter aphrophilus is a Gram negative, oxidase and catalase negative, capnophilic, fermentative coccobacillus with $\mathrm{X}$ independence on primary isolation [1]. It is a member of the HACEK group of organisms (Haemophilus, Aggregatibacter, Cardiobacterium, Eikenella and Kingella) [2] and was formerly named Haemophilus aphrophilus or Haemophilus paraphrophilus.

A. aphrophilus is part of the normal oropharyngeal flora and has already been described as the causative agent of brain abscesses, empyema, meningitis, sinusitis, otitis media, bacteriemia, pneumonia, osteomyelitis, peritonitis, endocarditis and wound infections [1].

The Bartholin's glands are two little hormonodependent glands that are located symmetrically in the posterior region of the vaginal opening and that take part in mucus secretion and vaginal lubrification. Acute bartholinitis is generally due to the surinfection of a gland cyst caused by the obstruction of the excretory duct. The main clinical sign is a painful swelling in the posterior area of the labia majora [3].

\footnotetext{
* Correspondence: sandrine.castelain@u-picardie.fr

${ }^{1}$ Department of Bacteriology, Amiens University Hospital, Amiens, France ${ }^{2}$ Microbiology Research Unit, EA4294, Jules Verne University of Picardie, Amiens, France
}

(c) 2016 The Author(s). Open Access This article is distributed under the terms of the Creative Commons Attribution 4.0 International License (http://creativecommons.org/licenses/by/4.0/), which permits unrestricted use, distribution, and reproduction in any medium, provided you give appropriate credit to the original author(s) and the source, provide a link to the Creative Commons license, and indicate if changes were made. The Creative Commons Public Domain Dedication waiver (http://creativecommons.org/publicdomain/zero/1.0/) applies to the data made available in this article, unless otherwise stated.

\section{Case presentation}

A 33-year-old non pregnant woman (G3P1) was admitted to the obstetric emergency ward of Amiens Teaching Hospital (Amiens, France) for a 3-day genital pain located in the left labia majora. Her past medical history was unremarkable (term delivery, normal blood sugar, no previous history of diabetes in her family) except for a recurrent left Bartholin's gland abscess. On admission, she was afebrile and presented no urinary functional signs. Gynecologic examination revealed a large abscess which was incised and drained under spinal anesthesia. The purulent fluid was sent for culture to the bacteriology laboratory.

Gram staining of the pus showed a lot of neutrophils with Gram negative coccobacilli and the next day cultures revealed a pure culture of small, high-convex, grey 
colonies only growing on chocolate culture medium (Fig. 1) (Polyvitex PVX, bioMérieux, France) under $5 \%$ $\mathrm{CO}_{2}$. Catalase and oxidase reactions were negative. The isolate was identified with the use of matrix-assisted laser desorption ionisation-time of flight mass spectrometry (MALDI-TOF MS; Bruker Daltonik GmbH, Germany; MALDI Biotyper 2.2) as A. aphrophilus. Identification was confirmed by sequencing the 16S RNA gene as previously described [6]. The isolate was identified as $A$. aphrophilus with a maximum identity of $100 \%$ for A. aphrophilus strain NJ8700 (GenBank accession number CP009230.1). Susceptibility testing was performed using E-test (bioMérieux, France) on chocolate culture medium (Polyvitex PVX, bioMérieux, France) under $5 \% \mathrm{CO}_{2}$. The minimal inhibitory concentrations (MICs) for amoxicillin, amoxicillin-clavulanic acid, ceftriaxone, tetracycline and rifampicin were $0.38 \mathrm{mg} / \mathrm{L}, 0.38 \mathrm{mg} / \mathrm{L},<0.016 \mathrm{mg} / \mathrm{L}, 1.0 \mathrm{mg} / \mathrm{L}$ and $0.25 \mathrm{mg} / \mathrm{L}$ respectively.

The patient received no antibiotics for the treatment of this left bartholinitis and the clinical course was favourable. She went home a few days later with only local care and analgesics. A cold resection was recommended by the surgeon who operated on her to prevent any recurrence but could not have been done.

Unfortunately, the woman came back to the hospital 5 months later for a new abscess of the Bartholin's left gland. A wild-type Escherichia coli was isolated and the treatment was the same as for the previous abscess, except that a marsupialization was performed.

\section{Discussion}

A. aphrophilus was first described by Khairat [7] in 1940 (initially as Haemophilus aphrophilus) after it had been isolated from a patient with infectious endocarditis. This bacterium causes many different kinds of infections (more or less severe) but has never been documented as the causative agent of bartholinitis.

Bartholinitis is quite a common problem in clinical practice and can be caused by a wide variety of microorganisms [3]. First, Enterobacteriaceae (mainly E. coli) followed by capnophilic species such as Haemophilus influenzae and N. gonorrhoeae [8]. Anaerobic bacteria from the vaginal flora have also been implicated, mostly in polymicrobial abscesses due to both aerobes and anaerobes [5]. C. trachomatis should be considered as a rare cause of bartholinitis.

Nulligravida women between 20 and 29 years old and patients with diabetes are the most affected populations [9]. In our case, the aetiology couldn't be found. Indeed, the patient was 33 years old, she had a son, her blood sugar was normal $(4.4 \mathrm{mmol} / \mathrm{L}$ with an empty stomach) and there was no previous history of diabetes in her family.

Following bartholinitis, haemorrhagic or infectious complications can occur such as septicaemia, pelviperineal abscesses or necrotizing fasciitis, which remains a rare phenomenon. The recurrence rate has been evaluated between 5 and $15 \%$ after a first episode and this rate is not modified by marsupialisation [10]. Concerning our case, it was the third episode of bartholinitis (previously a Streptococcus anginosus had been isolated; and for the second one, no bacteriological sample had

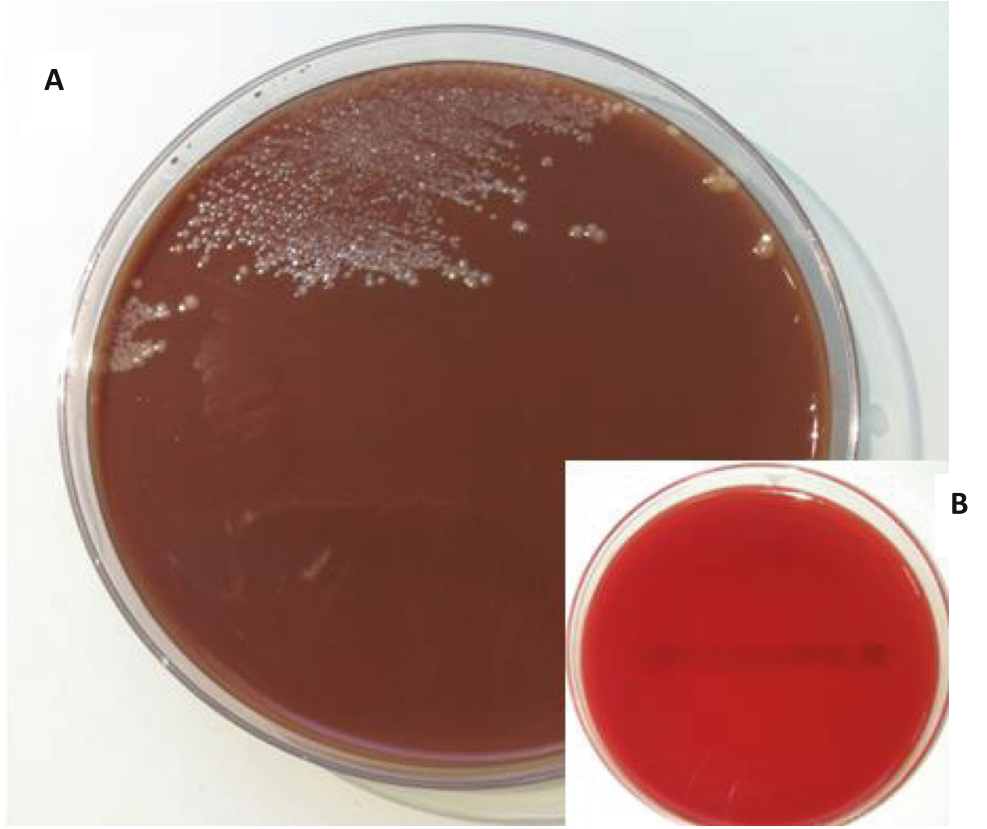

Fig. 1 Culture of A. aphrophilus on chocolate agar (a) and blood agar (b) plates after 48 h under $5 \%$ CO2 
been collected) and 5 months later, the patient presented a new recurrence.

It has been suggested that the change in sexual practices modifies the ecology of Bartholin's glands abscesses [11]. While a diminution of infections due to bacteria involved in sexually transmitted diseases can be observed nowadays, abscesses caused by micro-organisms from the gastro-intestinal flora, but also from the oro-pharyngeal flora are mostly described. For example, Streptococcus pneumoniae, a commensal of the upper respiratory tract, can be responsible for such infections as a result of orogenital contact $[3,11]$. Another case of Bartholin's gland abscess caused by a micro-organism from the oropharyngeal flora, Neisseria sicca, was reported in the literature by Berger et al. in 1988 [12].

The recommended treatment for a Bartholin's gland abscess is surgical incision and draining [5]. However, the introduction of antibiotics for the treatment of such infections is much discussed. Three opinions emerge from the literature. First, antibiotics introduced as a complement to surgery are advised (an intraoperative intravenous injection) although long term antibiotherapy is considered useless. Secondly, no other treatment than marsupialization is advocated. Finally, antibiotic treatment can be considered in a context of pregnancy [5]. Our patient received no antibiotics for any of her four episodes of bartholinitis.

\section{Conclusion}

An overview of the literature makes us note that A. aphrophilus has never been documented in acute bartholinitis. However, this organism, part of the oro-pharyngeal flora, has already been described as the causative agent of many different kinds of infections.

Recurrent bartholinitis in our case highlights the importance of an effective treatment of this type of infection.

\section{Acknowledgments}

We are grateful to Dr Odile Gagneur and Dr Melyne Lombart for their expert clinical assistance.

\section{Availability of data and materials}

All data included within the article

\section{Authors' contributions}

Acquisition of data: MC, EP, VD. Analysis and interpretation of data: MC, EP, VD. Critical revisions of the manuscript for important intellectual content: $M C_{\text {, }}$ EP, RG, VD. Study supervision: MC, SC, VD. All authors read and approved the final manuscript.

\section{Competing interests}

The authors declare that they have no competing interests.

\section{Consent for publication}

Written informed consent was obtained from the patient for publication of this Case report. A copy of the written consent is available for review by the Editor of this journal.

Ethics approval and consent to participate Not applicable.
Received: 7 January 2016 Accepted: 11 October 2016

Published online: 18 October 2016

References

1. Maraki S, Papadakis IS, Chronakis E, et al. Aggregatibacter aphrophilus brain abscess secondary to primary tooth extraction: Case report and literature review. J Microbiol Immunol Infect. 2013. doi:10.1016/j.jmii.12.007.

2. Patel SR, Patel NH, Borah A, et al. Aggregatibacter aphrophilus pacemaker endocarditis: a case report. BMC Res Notes. 2014;7:885.

3. Sing A, Roggenkamp A, Kress K, et al. Bartholinitis Due to Streptococcus pneumoniae: Case Report and Review. Clin Infect Dis. 1998;27(5):1324-5.

4. Bleker OP, Smalbraak DJ, Schutte MF. Bartholin's abscess: the role of Chlamydia trachomatis. Genitourin Med. 1990;66(1):24-5.

5. Kessous R, Aricha-Tamir B, Sheizaf B, et al. Clinical and microbiological characteristics of Bartholin gland abscesses. Obstet Gynecol. 2013:122(4):794-9.

6. Teranishi $\mathrm{H}$, Ohzono N, Inamura N, et al. Detection of bacteria and fungi in blood of patients with febrile neutropenia by real-time PCR with universal primers and probes. J Infect Chemother. 2015;21(3):189-93.

7. Khairat O. Endocarditis due to a new species of Haemophilus. J Pathol Bacteriol. 1940;50:497-505.

8. Quentin R, Pierre F, Dubois M, et al. Frequent isolation of capnophilic bacteria in aspirate from Bartholin's gland abscesses and cysts. Eur J Clin Microbiol Infect Dis. 1990;9(2):138-41.

9. Roberts DB, Hester LL. Progressive synergistic bacterial gangrene arising from abscesses of the vulva and Bartholin's gland duct. Am J Obstet Gynecol. 1972;114:285-91.

10. Horowitz IR, Buscema J., Woodruff JD. Surgical conditions of the vulva, in Rock JA, Thompson JD (eds): The Linde's Operative Gynecology. 8th ed. Philadelphia, Lippincott-Raven, 1997; pp 890-893.

11. Parvathi S, Imara A, Thoduka T. Bartholinitis caused by Streptococcus pneumoniae: Case report and review of literature. Indian J Pathol Microbiol. 2009;52(2):265.

12. Berger SA, Gorea A, Peyser MR, et al. Bartholin's gland abscess caused by Neisseria sicca. J Clin Microbiol. 1988;26(8):1589.
Submit your next manuscript to BioMed Central and we will help you at every step:

- We accept pre-submission inquiries

- Our selector tool helps you to find the most relevant journal

- We provide round the clock customer support

- Convenient online submission

- Thorough peer review

- Inclusion in PubMed and all major indexing services

- Maximum visibility for your research

Submit your manuscript at www.biomedcentral.com/submit
Biomed Central 